\title{
CLINICAL SCIENCES
}

\section{BILATERAL NEPHRECTOMY OF HUGE POLYCYSTIC KIDNEYS ASSOCIATED WITH A RECTUS ABDOMINIS DIASTASIS AND UMBILICAL HERNIA}

\author{
Marcos Lucon, Luiz Estevam Ianhez, Antonio Marmo Lucon, Jose L. Chambô, \\ Emil Sabbaga, Miguel Srougi
}

Lucon M, Ianhez LE, Lucon AM, Chambô JL, Sabbaga E, Srougi M. Bilateral nephrectomy of huge polycystic kidneys associated with a rectus abdominis diastasis and umbilical hérnia. Clinics. 2006;61(6):529-34.

BACKGROUND: Patients with end-stage renal failure due to huge autosomal dominant polycystic kidney disease usually have an umbilical hernia and rectus abdominis diastasis, which are very troublesome. Pretransplant bilateral nephrectomy techniques does not manage the umbilical hernia and rectus abdominis diastasis. We report our experience in performing bilateral nephrectomy and repairing the rectus abdominis diastasis and umbilical hernia through the one, small incision.

METHODS: Four patients aged 37 to 43 years with huge polycystic kidneys, an umbilical hernia, and a rectus abdominis diastasis underwent bilateral pretransplant nephrectomy through a midline supraumbilical incision including the umbilical hernia defect. The kidneys were removed through this incision. The incision was closed with the transposition of rectus abdominis muscle, pants-over-vest-style, to correct the diastasis and the umbilical hernia.

RESULTS: The average operative time was 160 minutes (range, 130-180); the average larger kidney size was $33 \mathrm{~cm}$ (range, $32-34$ $\mathrm{cm}$ ); no major complications occurred; one patient who had preoperative low hemoglobin required blood transfusion. Patients were discharged from the hospital on postoperative day 7 with an esthetically pleasing belly, no rectus abdominis diastasis, and no umbilical hernia. One to two months after bilateral nephrectomy, the patients received a live donor kidney with an uneventful outcome.

CONCLUSION: A midline supraumbilical incision is an excellent approach for bilateral nephrectomy of huge polycystic kidneys. In addition, an umbilical hernia and rectus abdominis diastasis may be successfully repaired through same incision with good cosmetic results.

KEYWORDS: Adult polycystic kidney disease. Nephrectomy. End-stage renal failure. Autosomal dominant polycystic kidney disease.

\section{INTRODUCTION}

Autosomal dominant polycystic kidney disease (ADPKD) is a hereditary disorder in which the ADPKD-1 or ADPKD2 gene has been mutated and the synthesis of polycystin 1 or polycystin 2 proteins has been altered. ${ }^{1}$ Continuous and progressive compression and destruction of renal parenchyma by the cysts lead to renal failure that reaches its final stage

Department of Urology, São Paulo University Medical School - São Paulo/ SP, Brazil.

Email: mlucon@uol.com.br

Received for publication on August 04, 2006.

Accepted for publication on August 29, 2006. and requires dialysis or transplantation by the age of 60 in $50 \%$ of the patients. ${ }^{2}$ Nephrectomy is not mandatory for transplantation in these patients, and in fact the majority of patients do not need it. Unilateral or bilateral nephrectomy is only necessary in those patients with persistent pain, infection, difficulty in breathing, or when the kidneys are so big that there is insufficient room available in the lower abdomen to graft a new kidney. In this latter case, umbilical hernia and rectus abdominis diastasis are usually found and are really troublesome for the patient. Long midline or transverse incisions or flank incisions, hand-assisted or laparoscopic, are the techniques described, but none of these manages the umbilical hernia or rectus abdominis diastasis. 
An experience in performing bilateral nephrectomy with the rectus abdominis diastasis and umbilical hernia repaired through the same small incision is reported.

\section{MATERIALS AND METHODS}

One woman and 3 men aged 37 to 43 years with huge polycystic kidneys and end-stage renal failure met the necessary criteria to receive a live donor kidney transplant. Physical examination and MRI revealed 2 enormous kidneys reaching the iliac fossa, taking up almost the entire abdomen and leaving no room for a transplant (Figure 1). Furthermore, all the patients had an umbilical hernia of about $2 \mathrm{~cm}^{3}$ and palpable rectum abdominis diastasis that was easily seen when the patient sat or stood (Figure 2). In this latter posture the diastasis presented the shape of a ship's keel. The patients said that the volume of the abdomen made them feel extremely uncomfortable and that the umbilical hernia together with the rectus abdominis diastasis made their quality of life much poorer. All of them were taking erythropoietin, and 3 of them had normal levels of hemoglobin and hematocrit. The fourth patient, the only one positive for HIV, had presented various episodes of infection in cysts and had low levels of hemoglobin and hematocrit.
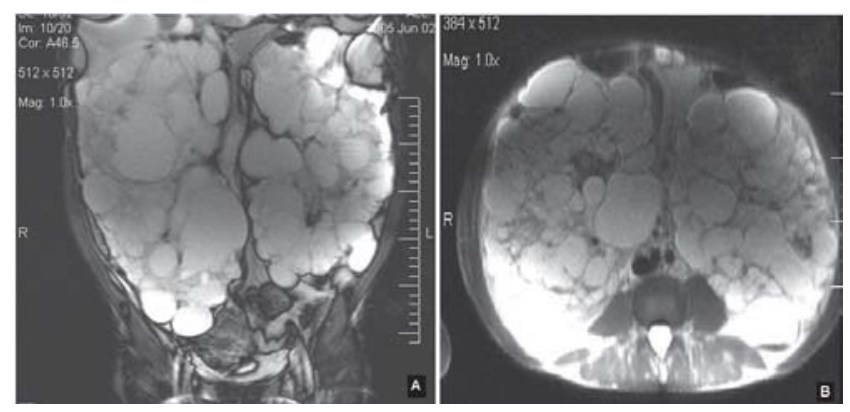

Figure 1 - MRI of large kidneys occupying almost the entire abdomen. A coronal view; $\mathrm{B}$ - transversal view

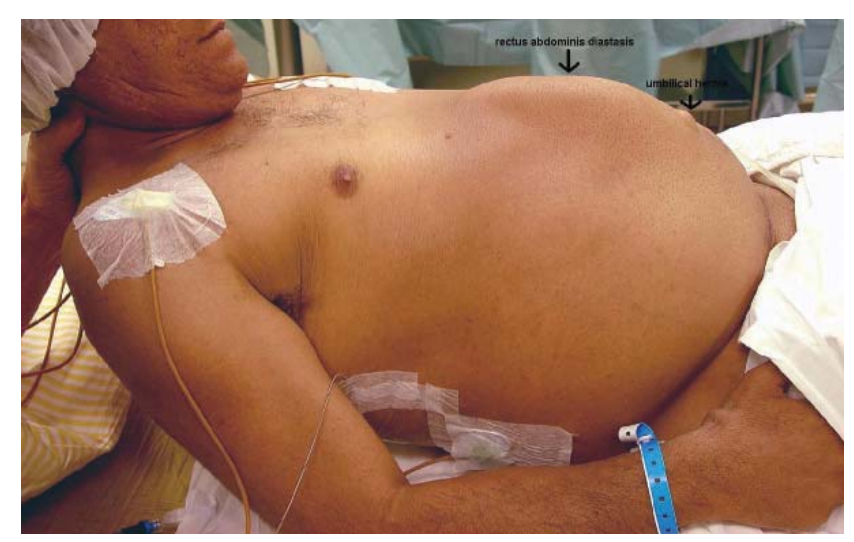

Figure 2 - Rectus abdominis diastasis and umbilical hernia in a ADPKD patient
The pretransplantation bilateral nephrectomy was performed in all patients as described below:

Step 1: Through a midline supraumbilical incision, the peritoneal cavity was accessed. No autostatic retractor was used due to the large volume of the kidneys, assistants providing adequate exposure of the operative field.

Step 2: The right colon was mobilized, exposing the right kidney.

Step 3: Careful dissection of the right renal hilum was done, identifying the renal artery and vein. Both were then secured and cut.

Step 4: The complete mobilization of the right kidney was then performed. Care was taken with the perirenal neovascularization to provide a bloodless operative field. The adrenal gland was spared in all cases.

Step 5: After the ureter was clipped and cut, the right kidney was extracted with adequate incisional mobilization.

Step 6: The left kidney was tackled with the same procedure. Mobilization of the spleen and pancreas was sometimes necessary to adequately expose the renal hilum.

Step 7: After the retroperitoneal hemostasis was revised, the ascending and descending colons were fixed in their original positions.

The abdominal wall closure was performed as follows:

Step 1: The rectus aponeurosis was released at its lateral edge bilaterally;

Step 2: The double-breasted technique was then employed to correct the umbilical hernia and/or the rectus abdominal diastases caused by the chronic distention. A full thickness suture line was made using U shaped stitches to overlap the aponeurosis, as follows:

Step 2a: Initially, the full thickness stitch entered the anterior aponeurosis at the lateral edge of the left rectus abdominis and penetrated the peritoneum from the outside inwards. It emerged from the medial edge of the contralateral rectus abdominis, from the inside outwards, and entered the same medial edge from outside inwards. Then, it was continued through the lateral border of the left rectus abdominis from the inside outwards, thus forming the "U". The stitch was not knotted (Figure 3);

Step 2b: Additional sutures were similarly made. This first suture line was then tightened, with the right rectus lying underneath the left one;

Step 3: Second-line sutures were placed along the medial edge of the left rectus abdominis aponeurosis and 
anterior aponeurosis of the right rectus. In this manner, the left rectus abdominis aponeurosis was firmly attached over the right one (Figure 4);

Step 4: Subcutaneous tissue was closed with absorbable interrupted suture. No subcutaneous drainage was needed;

Step 5: The skin was closed with interrupted stitches.

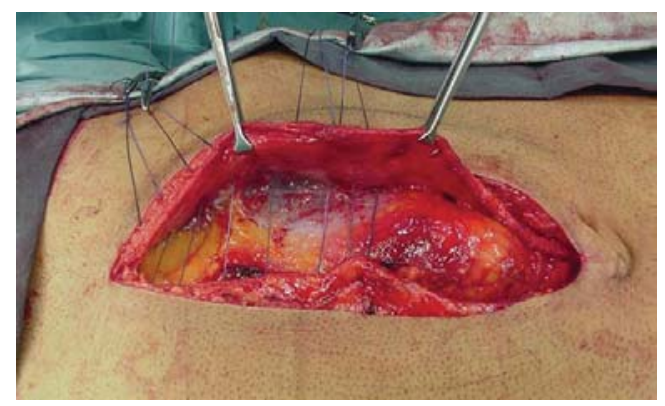

Figure 3 - U-shape stitches allowing the overlapping of the borders of the incision

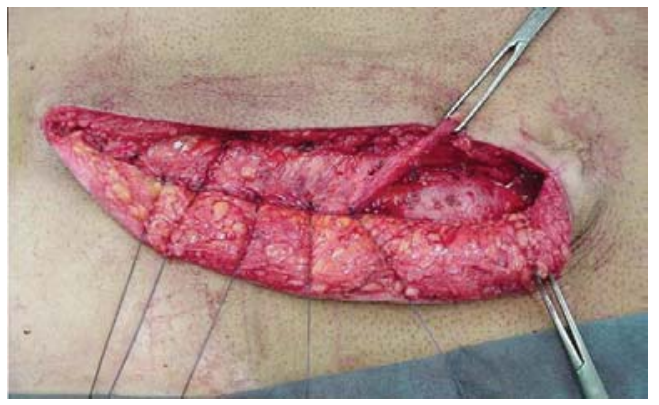

Figure 4 - Final aspect of one over the other overlapped borders of the incision

\section{RESULTS}

The average larger kidney size was $33 \mathrm{~cm}$ (range, 32$34 \mathrm{~cm}$ ). Average operative time was 160 minutes (range, 130-180 minutes). Only 1 patient, with preoperative low hemoglobin, required blood transfusion. No major complications occurred. Three of the patients were discharged from hospital on postoperative day 7 with an esthetically pleasing belly, no rectus abdominis diastasis, and no umbilical hernia (Figure 5). The fourth patient in the same postoperative condition remained in hospital for clinical control of his HIV-positive condition. One or two months after bilateral nephrectomy, each patient received a live donor kidney, with uneventful outcomes.

\section{DISCUSSION}

The most serious complication of ADPKD is end-stage renal failure, which occurs earlier in bearers with ADPKD

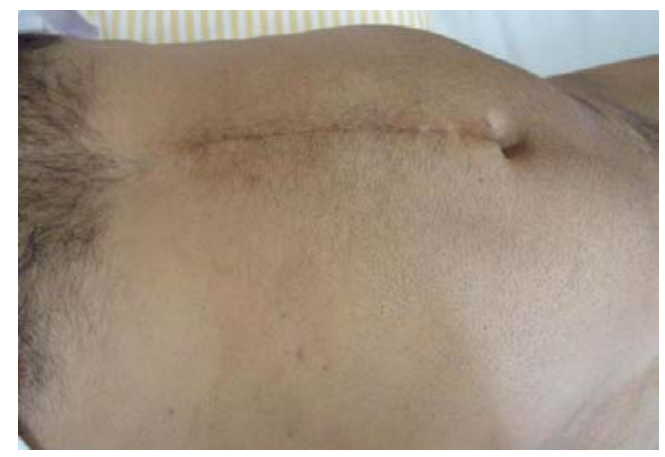

Figure 5 - Esthetically pleasing belly with no rectus abdominis diastasis and no umbilical hernia after bilateral nephrectomy for ADPKD

gene type 1 than in those with type 2; this may begin at any age between 2 and 80 years. $^{2}$ Most of the patients may be treated with chronic dialysis or by transplant without the removal of the original kidneys, which maintain a low level of production of aqueous diuresis and erythropoietin during the period of dialysis. In fact, patients with ADPKD on dialysis have better survival rates than patients with other diseases. ${ }^{3}$ The survival of patients with ADPKD who have received a renal transplant is equal to that of transplant patients with other diseases, and with better quality of life than that of patients treated with hemodialysis. ${ }^{4}$ However, there are situations in which unilateral or bilateral nephrectomy needs to be undertaken for the control of pain, hemorrhage, calculosis, or infection that does not responded to other kinds of treatment, as well as for those patients with very large kidneys and a poorer quality of life. Furthermore, this latter group of patients has umbilical hernia and rectus abdominis diastasis as a result of progressive intense chronic distention of the abdominal wall by the huge kidneys.

Bilateral nephrectomy has been reported to be performed through the midline transabdominal approach, ${ }^{5,6}$ lumbotomy, ${ }^{7}$ hand-assisted, ${ }^{8-10}$ or laparoscopy, ${ }^{11}$ but none of these reports has described the repair of the rectus abdominis diastasis or umbilical hernia. Open nephrectomies are often followed by significant complications, in some cases leading to splenectomy, because of splenic lacerations that may occur during renal dissection; they may also lead to partial or complete adrenalectomy because of adrenal gland injury that occurs during blind blunt dissection of the upper pole of the kidney; other possible complications are subphrenic abscesses, ${ }^{5}$ incisional hernias, ${ }^{11}$ or to death of undescribed cause. ${ }^{12}$ For these reasons, the hand-assisted and laparoscopic techniques have recently been more highly valued. In a series in which the handassisted technique was used, an infraumbilical medial incision of 7-14 cm length combined with 3 port incisions were reported. ${ }^{9}$ In other studies, a medial incision of $7 \mathrm{~cm}$ 
incorporating the umbilicus, ${ }^{8}$ calling for aspiration to empty the cyst, ${ }^{8,10}$ with surgical time varying between 4.8 and 5.5 hours, were reported. With the laparoscopic technique, an incision of 8 to $10 \mathrm{~cm}$ was necessary, with surgical time of 4.4 hours. $^{11}$

The technique described in our report requires incisions that are slightly larger than those of the hand-assisted and laparoscopic techniques, but it does not require routine aspirations for emptying cysts, nor does it require morcellation of the kidneys (Figure 6); the average surgical time is shorter (160 minutes). If there is no pre-existing anemia, there is no need for transfusion, thus reducing the possibility of sensitization of the future receiver. Furthermore, this technique has the advantage of correcting both the umbilical hernia and rectus abdominis diastasis, thus leading to the full recovery of the patient.

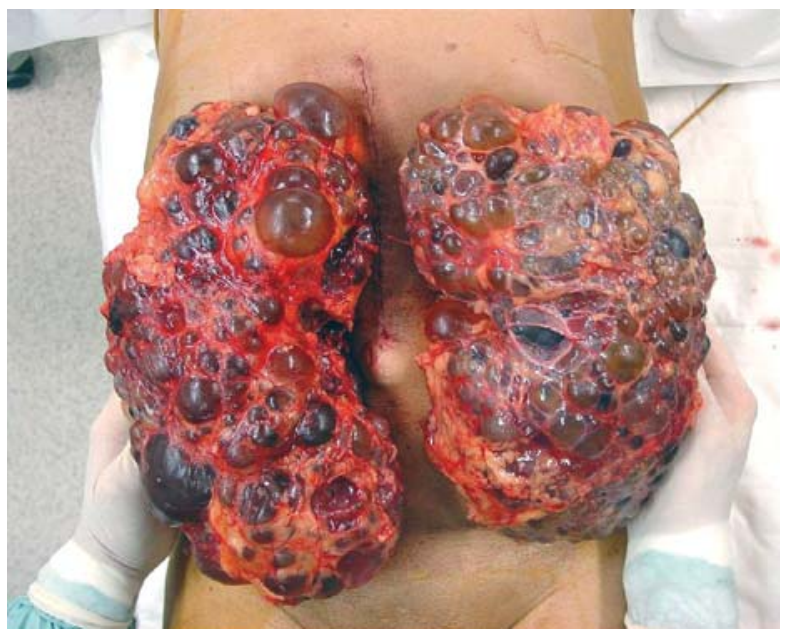

Figure 6 - The incision of much smaller size than the kidney, with no emptying of the cyst and no morcellation of the kidney required

\section{RESUMO}

Lucon M, Ianhez LE, Lucon AM, Chambô JL, Sabbaga E, Srougi M. Nefrectomia bilateral para doença renal policística gigante associada à diástase do reto abdominal e hérnia umbilical. Clinics. 2006;61(6):529-34.

INTRODUÇÃO: Pacientes com insuficiência renal terminal por Doença Renal Policística Autossômica Dominante geralmente apresentam hérnia umbilical e diástase de músculo reto abdominal, que são muito problemáticas. Técnicas de nefrectomia bilateral pré-transplante não dão atenção à hérnia umbilical e à diástase do músculo reto abdominal. Relatamos nossa experiência com nefrectomia bilateral e correção da diastase de músculo reto abdominal e hérnia umbilical através de uma única pequena incisão.

MÉTODOS: Quatro pacientes com idade entre 37 a 43 
anos com Doença Renal Policística Autossômica Dominante gigante, hérnia umbilical e diástase do múculo reto abdominal foram submetidos à nefrectomia bilateral pré-transplante através de incisão mediana supra-umbilical incluindo o defeito herniário umbilical. Os rins foram removidos através da pequena incisão mediana. A incisão foi fechada com transposição do músculo reto abdominal tipo jaquetão para corrigir a diastase e a hernia umbilical.

RESULTADOS: O tempo operatório médio foi 160 minutos (130-180); o tamanho médio do maior rim foi $33 \mathrm{~cm}$ (32-34); não ocorreram grandes complicações; um paciente, que tinha baixo nível de hemoglobina préoperatório e precisou de transfusão sanguiínea. Pacientes receberam alta hospitalar no $7^{\circ}$ pós-operatório com abdome de boa aparência, sem diástase de músculo reto abdominal e sem hérnia umbilical. Os pacientes receberam enxerto renal de doador vivo um ou dois meses após a nefrectomia bilateral, sem intercorrências.

CONCLUSÃO: A incisão mediana supra-umbilical é uma abordagem excelente para nefrectomia bilateral de rins policísticos gigantes. Além disso, a hernia umbilical e a diastase de músculo reto abdominal podem ser corrigidas com sucesso pela mesma incisão, com bons resultados cosméticos.

UNITERMOS: Doença renal policistica autossômica dominante. Nephrectomy. Insuficiência renal. Doença renal policística do adulto.

\section{REFERENCES}

1. Sutters M, Germino GG. Autosomal dominant polycystic kidney disease: molecular genetics and pathophysiology. J Lab Clin Med. 2003;141:91.

2. Gabw PA. Autosomal dominant polycystic kidney disease. New England J Med. 1993;329:332.

3. Chester AC. Polycystic kidney disease and chronic hemodialysis. Clin Nephrol. 1978;10:1929.

4. Mendelson DC, Harging ME, Cardella CJ, Cook GI, Uldall PR. Management of end-stage autosomal dominant polycystic kidney disease with hemodialysis and transplantation. Clin Nephrol. 1988;30:315.
5. Bennett AH, Stewart W, Lazarus JM. Bilateral nephrectomy in patients with polycystic renal disease. Surg Gynecol Obst. 1973;137:819.

6. Glassman DT, Nipkow L, Barlett ST, Jacobs SC. Bilateral nephrectomy with concomitant renal graft to transplantation for autosomal dominant polycystic kidney disease. J Urol. 2000;164:661.

7. Darby CR, Crauston D, Raine AEG, Monis PJ. Bilateral nephrectomy before transplantation: indications, surgical approach, morbidity and mortality. Brit J Surg. 1991;78:305.

8. Rehman J, Landman J, Andrenoni C, Mac Dougall EM, Clayman RU. Laparoscopic bilateral hand assisted nephrectomy for autosomal dominant polycystic kidney disease: initial experience. J Urol. 2001; $166: 42$. 
Lucon $\mathrm{M}$ et al.

9. Senkis MA, Crane J, Munch LC. Bilateral hand assisted laparoscopic nephrectomy for autosomal dominant polycystic kidney disease using a single midline HandPort incision. Urology. 2002;59:32.

10. Pinto MA, Juliano RV, Machado MT, Borrelli M, Wroclawski E. Handassisted nephrectomy in a patient with adult polycystic disease. Sao Paulo Med J. 2002;120:189.

11. Gill IS, Kaouk JH, Hobart MG, Sung GT, Schweizer DK, Braun WE. Laparoscopic bilateral synchronous nephrectomy for autosomal polycystic kidney disease: the initial experience. J Urol. 2001;165:1093.
12. Rayner BL, Cassidy MJD, Jacobsen SE, Pascol MD, Pontin AR, Van Zyl Smit R. Is preliminary nephrectomy necessary in patients with autosomal dominant polycystic kidney disease undergoing renal transplantation? Clin Nehrol. 1990;34:122.

13. Lee DI, Clayman RU. Hand assisted laparoscopic nephrectomy in autosomal dominant polycystic kidney disease. J Endourol. 2004;18:379. 